\title{
Visser, P J 1997 - Bemoeienis en Getuigenis: Het leven en de missionaire theologie van Johan H Bavinck (1894-1964)
}

\author{
Zoetermeer: Uitgeverij Boekencentrum. 340 bladsye. Prys: Onbekend
}

\section{Resensent: Prof H G van der Westhuizen}

P J Visser, 'n Hervormde predikant, tipies Nederlands uit 'n familie van predikante, het 'n pragtige proefskrif gepubliseer oor die Gereformeerde sendingwetenskaplike, J H Bavinck. Daarby beloof hy ook om dit in Engels te vertaal waarvan die titel op die binneblad reeds verskyn: Solicitude and witness. Die Nederlandse uitgawe behoort aan ons studente voorgeskryf te word en die latere Engelse uitgawe aan studente wat ongelukkig maar net Engels magtig is.

Alles wat hoort by 'n netjiese, volledige, diepgaande Nederlandse proefskrif, is in hierdie uitgawe byeen: Voorin 'n volledige inhoudsopgawe van sewe bladsye, 'n lys van afkortings, 'n Woord vooraf, en daarby 'n pragtige foto van J H Bavinck. Agterin is vyftien bladsye van geraadpleegde primêre en sekondêre bronne. Verder ses bladsye dubbelkolom Nameregister. Daar is ook drie Appendikse waarvan die tweede en die derde baie interessant is. Die tweede een bevat die name en proefskrifonderwerpe van promovendi van prof $\mathrm{J} \mathrm{H}$ Bavinck. Onder die agtien studente wat onder hom gepromoveer het, is bekende name soos byvoorbeeld J Verkuyl, J Blauw, A G Honig, L Zielhuis, H R Boer, J C Gilhuis, J van den Berg. Interessant dat vyf Suid-Afrikaners ook onder hom gepromoveer het: P P A Kamfer (1955), C I van Heerden (1957), G C Oosthuizen (1958), J J F Durand (1961) en B A Müller (1961).

Die derde Appendiks bevat die volledige rapport oor sending wat voor die Gereformeerde Sinode Middelburg in 1896 gedien het. Bavinck se sendingwerk en sendingdenke is grondig deur hierdie rapport gesteun.

\section{Skema}

In 'n Inleiding word die motivering wat Bavinck se opvolger, Johannes Verkuyl, aan Visser gegee het om die nagelate gedagtegoed van Bavinck te analiseer en te orden, vind. 'n Verklaring van die titel volg en dan 'n uiteensetting van die skema van die navorsing.

As Hervormers weet ons nie veel meer van hierdie Gereformeerde teoloog as sy Inleiding in de Zendingswetenschap (1954) nie. Visser bring nou werklik alle geskrifte en korrespondensie van Bavinck byeen, waarvan daar honderde is, asook gesprekke met persone wat Bavinck geken het.

Dit is die waarde van hierdie boek dat dit ook die agtergronde van al Bavinck se sendingdenke sistematiseer. Waar Bavinck in der waarheid in die tradisie van G Voet, Gustav Warneck en andere die eerste volwaardige en praktiese Gereformeerde sendingwetenskaplike is, is dit 'n verrykende ervaring om nou die hele Bavinck in één publikasie te kan hanteer. Dit sou 'n arm dag vir Gereformeerde en Hervormde teoloë wees om by Bavinck verby te gaan.

Die voorgeskiedenis van Bavinck, nageslag van 'n Duitser uit Bentheim, wat reeds dié van in 1594 gehad het, word volledig beskryf. Dit is goed om vir 'n keer al die Bavinckke uitmekaar te ken. Jan Bavinck (1826-1909) word in 1845, na staking van stemme per loting aangewys om as Gereformeerde predikant opgelei te word. Hy word deur W A Kok onder andere te Hoogeveen opgelei en hy trou in 1850 met mej Gesina Magdalena Holland, '... een doortastende en kordate vrouw.' 
Jan Bavinck se oudste seun, Herman Bavinck (1854-1921), is die beroemde dogmatikus. Herman se broer Coenraad Bavinck (1866-1941) is ons J H Bavinck se vader. Ook Coenraad was predikant maar baie beskeie, dog intelligent, vroom en korrek.

Die hele lewensloop van Bavinck word in 'n deeglike maar oorsigtelike biografie van meer as vyftig bladsye gegee. Die verskillende fases in Bavinck se lewe as sendingleraar op Java, leraar in Nederland, professor en so meer, vorm insiggewende agtergrond vir sy aanvanklike meer psigologiese en later meer teologiese benadering in die kerkwerk.

\section{Missionêre teologie}

Baie interessant is die behandeling van die invloed in Godsdiensteologiese verband wat op Bavinck ingewerk het: Augustinus, Calvyn, Schleiermacher, Otto, Kuyper, Herman Bavinck, Karl Barth, Emil Brunner en Hendrik Kraemer.

In sendingteologiese verband het Gisbertus Voetius, die Sinode Middelburg (1896), Daubanton, Warneck en die ekumeniese sendingkonferensies baie invloed op Bavinck uitgeoefen, hoewel Bavinck natuurlik as 'n oorspronklike denker altyd sy kritiese opmerkings in gegronde feite en met groot nederigheid geopenbaar het. Veral waar die ekumene tot maatskaplike programme en sosiale beleide oorgaan, het Bavinck hom geskaar by, soos Van Andel gesê het in 1929 (bl 104, voetnoot 124): 'Zoo legt de Zending als prediking van het Evangelie wel in de harten de zaden, waaruit een Christelijke maatschappelijk en politiek leven opkomt, doch levert geen programma voor maatschappelijke hervormingen, noch een program van politieke actie.'

Visser bied 'n uitgebreide bespreking aan oor Bavinck se sistematiese missionêre teologie en sy gedagtes oor algemene openbaring en religieuse besef. Visser dui duidelik en krities aan hoe Bavinck 'n aanvanklike psigologiese benadering laat ontwikkel het tot 'n teologiese benadering (vgl bv bl 112, 113, 114). In hierdie ontwikkeling en selfs ommekering het die Hervormde $H$ Kraemer nie 'n geringe aandeel gehad nie (bl 114).

Die wetenskaplike objektiwiteit van Visser ten opsigte van Bavinck (en vele ander) se gebreke en tekortkominge kom menigmaal aan die lig (bv bl 122, 124, 132, 135, 160, 169, 177, 180, 181, 183, $200,201,202,246$ ). As wetenskaplike van integriteit is Visser altyd erkentlik teenoor medewetenskaplikes. So byvoorbeeld verwys hy altyd na die oorsprong van begrippe by iemand anders (bv morfologie, bl 143).

Besonder waardevol is die bespreking van Bavinck se sistematiese missionêre teologie ten opsigte van grondslag, wese, doel en benadering van die sending. Visser huiwer nie om krities-korrektief op te tree nie, byvoorbeeld: 'Op één belangrijke punt wijk ik echter af: de bespreking van het zendingsdoel laat ik voorafgaan aan die van de zendingsbenadering' (bl 164). In my handboek van 1990: Kerk en Kerstening, het ek reeds hierdie verandering weerspieël, waaronder Sendingleer genoem word: Sendingfundering, Sendingmotivering, Sendingdoel ... en daarna onder Sendingbeleid onder andere die benadering en metode.

'n Rykdom van inligting lê in die skatkamers van voetnote. In byvoorbeeld voetnoot 30 op bladsy 168 word gestel: 'De begrippen centripetaal en centrifugaal ... komen bij Bavinck nog niet voor, de gedachten die erin opgesloten zitten daarentegen wel.' Hierdie twee begrippe om die sendinggedagte in die Ou Testament en die Nuwe Testament onderskeidelik aan te dui, is in ons land veelal deur Bosch en andere gebruik. Professor Hugo du Plessis het in sy sendingboek 'n Banier van die volke in 1963 dié begripe breedvoerig behandel, en wel op voetspoor van 'n leerling van Bavinck, Johannes Blauw. In laasgenoemde se werk Gottes Werk in dieser Welt van 1961 word die begrippe op bladsy 43 gebruik. 
'n Tweede van honderde voorbeelde van die waardevolle voetnote van Visser is oor die sogenaamde dubbele fundering van die sending wat by die Protestantse Gustav Warneck en die Rooms-Katolieke Schmidlin gevind word. Bavinck, in navolging van Hans Schärer, wys dit van die hand. Visser wys in voetnoot 133 op bladsy 185 daarop dat die dubbele fundering foutiewelik geïnspireer is deur 'n foutiewe Vulgaat vertaling van Haggai 2:8.

Baie interessant is die wyse waarop Bavinck aanvanklik in navolging van die Sinode Middelburg (1896) die gemeente aangedui het om sending te doen teenoor sendinggenootskappe of sendingvriende. Dit is die redenasie dat die doop verbind is aan die sending in Matteus 28:19. En dit is alleen die gemeente, nie individue of sendinggenootskappe nie, wat mag doop (bl 186, 329).

'n Verdere voorbeeld van die waarde van Visser se navorsing, is die bespreking van Bavinck se definisies van sending (bl 191). Ons weet dat Bavinck in sy Inleiding in de zendingswetenschap (1954) twee definisies gee - 'n voorlopige en 'n finale. My drukskripsie het 'n vergelyking van die twee gemaak. Maar Visser kompileer uit al Bavinck se werke vier volwaardige definisies, en toon die ooreenkomste, verskille en ontwikkeling daarin aan.

Die heldere hanteringvan begrippe soos Jodesending (bl 194, 198), evangelisasie en sending word waardeer (bl 196): 'Al is er zending en evangelisatie, qua benadering is er wel degelijk een verschil.'

Soms word deur moderne sendingwetenskaplikes die doel van sending, waarvan die uitbreiding van die kerk oftewel die plantatio ecclesiae, een is, betwyfel. Tereg hanteer Bavinck Voetius se drievoudige doel Gloria Divinae, conversio gentilium en plantatio ecclesiae 'op een algen wijze, door te stellen, dat zij drie aspecten zijn van én machtig oogmerk Gods, namelijk de komst en verbreiding van het koninkrijk Gods' (bl 199). Self het ek dit altyd beklemtoon dat 'daar 'n sterk samehangende band tussen al drie (is)' (Kerk en Kerstening, bl 11).

In die paragrawe oor grondlyne van sendingbenadering word pragtige teologiese motiverings aan die lig gebring. Die kerugmatiese benadering moet, behalwe Woordverkondiging, gepaardgaan met dade: "Het Woord is niet "redenering" geworden, of "betoon" geworden, maar het is "vlees" geworden, dat is: het is in echt menselijke levende gestalte in ons midden verschenen' (bl 206).

Bavinck het teenoor die Sinode Middelburg (1896), wat prast van hoofdiens (Woordverkondiging) en hulpdienste (soos onderwys en medies) krities liewer van kerndiens en newedienste gepraat (bl 210). Hierdie onderskeiding is sterk nagevolg in Suid-Afrika, byvoorbeeld deur H D A du Toit in sy Die Kerstening van die Bantoe, 1967, bladsy 162.

Waar die elenktiek 'n novisme van Bavinck is, weliswaar op voetspoor van Voet (bl 226), is dit die moeite werd om weer 'n slag volledig van sy gedagtegoed in hierdie verband kennis te neem, veral waar die term waarskynlik gaan verdwyn. As die term dalk met iets soos apologetiek of dialogiek vervang word, moet die inhoud nog steeds behou word (bl 247).

\section{Aktueel}

Baie aktueel is Visser se hantering van Bavinck oor: possessio (Bavinck se eie begrip), verhouding tussen ou en jong kerke, ekumene en die rasseproblematiek.

In die gedeelte oor Suid-Afrika se rasseprobleem kry 'n mens wel die gevoel dat die eiesoortige en unieke situasie van 'n klein Boerevolk wie se bestaan volledig bedreig word deur 'n massa van tien maal meer ander mense in dieselfde land, deur sowel Bavinck (as Visser?) nie goed ingesien is nie.

Tog het Bavinck aanvanklik positiewe waardering vir die beleid van afsonderlike ontwikkeling gehad: 'De idee van de apartheidspolitiek, als weg om tot een vreedzaam samen leven te komen van blanken en niet-blanken en als mogelijkheid om een gelijkwaardige positie te scheppen voor beide bevolkingsgroepen, wijst Bavinck niet af' (bl 281).

Op vele plekke blyk die sterk invloed wat die Hervormer, Hendrik Kraemer, op Bavinck gehad het (vgl bv bl 288). 
Ok om hierdie rede, maar ook omrede van sy teologiese statuur, sal die Hervormde Kerk armer wees as hulle Bavinck verloor. Merkwaardig dat Bosch in sy magnum opus, Transforming mission (1991), 587 bladsye, nie 'n woord oor Bavinck rep nie!

\section{Vraagtekens}

Op bladsy 193 voetnoot 187 sê Visser dat Bavinck al in 1945 'het gemaakte onderscheid door A Kuyer kritiseert.' Dit gaan om die onderskeid tussen heidene en Mohammedane. In voetnoot 215 op bladsy 197 se Visser: 'Bij G Voetius, van wie de onderscheiding tussen zending aan "heidene" en "Mohammedanen" afkomstig is.' Sou Visser verwysend na Kuyper 'n inhoudelike onderskeid bedoel en verwysend na Voetius ' $n$ terminologiese onderskeid - of is die verwysing na Kuyper verkeerd?

Op bladsy 272 word verwys na die Sinode Middelburg (1895), en so ook op bl 300 asof dié Sinode nie in 1896 was nie. Is dit 'n fout of was daar in 1895 ook 'n Sinode Middelburg?

Twee foute kom op bladsy 280 voor: 'De overwinning van de Nationalisten op de Verenigde Partij bij de verkiezing in 1953 leidde tot een verdergaande realisering van het in 1948 aangenomen apartheidsbeleid.' Die fout lê hierin dat dit lyk of die Nasionale Party eers in 1953 die Verenigde Party gewen het. Reeds in 1948 het die Nasionale Party met die beleid van apartheid aan bewind gekom. Met elke volgende verkiesing, soos in 1953, tot in die negentiger jare, het dié party aan bewind gebly.

Die tweede fout op bladsy 280 is 'n reeks spelfoute in voetnoot 177. Ek dui die korrekte aan: '... te weten de Nederduitse Gereformeerde Kerk, de Nederduitsch Hervormde Kerk en de Gereformeerde Kerke'.

Miskien kan by die gereedmaak van die Engelse uitgawe die tegniese kleinighede reggestel word, soos ook die verwydering van punte na 'n laaste syfer, byvoorbeeld op bladsy 284 (en ander): 8.1. Inleiding (korrek), 8.2. Orginaliteit ...

Die stelling dat 'zowel tijdens Bavincks leven als daarna wordt in de missiologiebeoefening van hervormde zijde nauwelijks of niet aan Bavinck gerefeerd op cen enkele uitsondering na' (bl 292). Dit is seker waar wat Nederland betref. Masr in Suid-Afrika het die Nederduitsch Hervormde Kerk sedert die vyftigerjare tot 1996 nog Bavinck se Inleiding in de zendingswetenschap voorgeskryf aan sy teologiese studente - meer as vier dekades se predikante is sendingkundig deur Bavinck gevorm. Van 1979 tot 1996 is die Engelse vertaling ook vir die Hervormde swart studente voorgeskryf by die Hervormde Teologiese Opleiding (HTO). Self het ek in vele geskrifte na Bavinck verwys, soos byvoorbeeld in Kerk en Kerstening (1990).

Op bladsy 307 kom lelike spelfoute voor in die kwalifikasie van Pro Veritate, christelike maandblad vir suidelike Afrika.

In Appendiks 1 op bladsy 324 word foutiewelik gedupliseer by die aanvullende bibliografie. Die artikel in Pro Veritate is reeds op bladsy 307 genoem. Ook die foute, soos hierbo uitgewys op bladsy 307, word gedupliseer op bladsy 324 !

\section{Laaste Opmerking}

Die jong geleerde Visser (gebore 24 Januarie 1959) het keiharde navorsing oor Bavinck gedoen. Hy het Bavinck se teologiese skering en inslag opgespoor en ons behoort in dieselfde spore met die nodige Bybelse normering te volg. 